\title{
LIVING DOCUMENTS, DYING ARCHIVES: TOWARDS A HISTORICAL ANTHROPOLOGY OF MEDIEVAL ARABIC ARCHIVES
}

\author{
DOCUMENTOS VIVOS, ARCHIVOS MORIBUNDOS: HACIA \\ UNA ANTROPOLOGÍA HISTÓRICA DE LOS ARCHIVOS \\ ÁRABES MEDIEVALES
}

TAMER El-Leithy

New York University

\begin{abstract}
Based on an analysis of several collections of Medieval Arabic documents, this paper argues for the study of "archiving practices", which selectively use documents as parts of wider social strategies of group formation and reproduction. This method also allows us to uncover the temporality (life-cycle) of documents and archives, including their dispersal, cycles of obsolescence and recycling; tactics of erasure, and deliberate destruction.

Key words: Arabic documents; Dhimmīs; Archives; Mamlūk Egypt-Syria.
\end{abstract}

Este trabajo es un análisis de varias colecciones de documentos árabes y propone estudiar las prácticas de archivo. Después de proponer un nuevo método de estudio de los documentos y los "archivos" o colecciones, este trabajo presta especial atención a las diferentes prácticas relacionadas con documentos; su producción, su uso, su conservación e, incluso, su destrucción deliberada.

Palabras clave: Documentos árabes; Dimmīes; Archivos; Mamelucos; Egipto.

\section{Introduction}

Medievalists are all too familiar with tricks of source survival. Often the frustrating and ostensibly random manner by which historical evidence has survived suggests a pattern as arbitrary as it is uneven. Yet the survival or absence of certain kinds -and genres- of sources have served as the lightening poles of a different kind of analysis; this is especially the case for archives from the pre-Ottoman Middle East, which have invited many interpretations.

For over a century, Orientalists and later scholars have unconditionally asserted this lack and marshaled it as evidence of various 
theses regarding the nature of Middle Eastern society, Islamic law, etc. Some have argued that this lacuna reflects Islamic law's inherent bias against written proof -as opposed to oral testimony- or Middle Easterners' negative disposition towards legal instruments, if not the law itself; and that this, in turn, retarded or prevented critical historical developments, most importantly, capitalism. ${ }^{1}$ Others concluded that the lack of archives evidenced the absence of a landed elite, resulting in a society of impoverished 'servants' and absolutist despots (Oriental despotism-or, in the later Weberian formulation, the patrimonial state).

While these conclusions have been slightly qualified by recent research, the underlying assertion -the absence of medieval Middle Eastern archives- has survived unchallenged; arguably, it has now even risen to common wisdom in the field. A recent contribution to this debate appears in Michael Chamberlain's thoughtful introduction to his study, Knowledge and Social Practice in Medieval Damascus. Chamberlain critically unpacks the assumptions of these Orientalist arguments: he keenly notes their ideological baggage, but he does not challenge the basic claim regarding the dearth of archives. In fact, he advances an even stronger version: for him, the absence is distinctly not an accident of source survival but a symptom of wider cultural practices. ${ }^{2}$ In medieval Europe, he argues, documents played a crucial role in elites' social competition and survival -as tools used to acquire, preserve, and transmit capital- which is why they were carefully preserved in archives. By contrast, Middle Eastern documents were not part of such practices of social competition because people did not have faith in them; this, in turn, explains why they allowed them to slide into oblivion. ${ }^{3}$ Chamberlain's thesis is not simply a story of lack: for him, social competition in Middle Eastern societies was waged in biographical dictionaries; it was here that elites struggled to control their image and shape the past, practices by which they

1 This is not only an academic or Orientalist view. The idea trickles on to the modern critcs of waqf (religious endowments), who called for their dismantling in order to advance capitalist economies within the region.

${ }^{2}$ Chamberlain, M., Knowledge and Social Practice, Cambridge, 1994. This is especially the case given that Middle Eastern societies were marked by comparatively higher literacy rates; the availability of paper; dry climates which facilitated its physical survival; the comparatively much higher rate of survival of other sources.

${ }^{3}$ Chamberlain, Knowledge and Social Practice.

Al-Qanțara XXXII 2, julio-diciembre 2011, pp. 389-434 ISSN 0211-3589 
secured their future. Here, the popularity and survival of biographical dictionaries evidences the care with which people protected them and the value they attached to them.

Chamberlain's is an argument from silence: because these documents don't survive - until today, we might add-, they were not archived in the first place. In other words, Chamberlain theorizes a historical accident into a practical (and cultural) logic; perhaps the most pernicious effect of such a totalizing argument is that it forecloses the space for any historical investigation of the social uses of medieval documents.

Chamberlain's strong argument is empirically untrue, as many collections of documents clearly attest: legal documents were routinely produced by notaries and courts; they were assiduously preserved by individuals and families, who later consulted and brandished these written forms of evidence in disputes and conflicts.

This article, however, is not simply a retort to Chamberlain's inaccurate thesis. Other scholars have directly rebutted these claims by presenting evidence of medieval archival collections -in most cases, social historians who rely on these legal documents to study topics like the history of taxation and fiscal administration; the military elite and their relations with the population; the 'ulama ' and their institutions of learning, etc. But while these studies now indisputably establish the existence of documentary collections, they have done little to advance our understanding of the specific workings of medieval Arabic archives. In a complete inversion of the absence thesis, they have merely asserted a presence where Chamberlain had claimed and theorized an absence.

Both camps, then, have been consumed with defensively denying larger narratives. Thus, despite its empirical error, Chamberlain's narrative continues to set the terms of the debate and arguably, the kind of questions that are asked of these newly presented sources in binary terms of absence/presence. One effect of this is the reduction of new scholarship to positivist and empiricist investigations -ones that do not interrogate the basic categories of our investigation, especially 'archive', and in so doing, implicitly accept concepts of European genealogy.

Beyond this unwitting conceptual debt to Chamberlain, documentary studies tend to share another implicit methodological premise regarding the value of documents in reconstructing social history: 
unlike narrative sources, documents in this account are more reliable, independent evidence, free of the problems of authorial manipulation and generic convention. These studies assume that documents allow unmediated and complete entry onto historical practice. ${ }^{4}$

Finally, given its legal provenance, most of the extant documentary evidence has mostly been studied by historians of law. While the steady discovery, editing and publication, and legal study of these documents have continued to shed light on the workings of Islamic law, they have also contributed to the 'disciplinary seclusion' of these documents. The focus on their legal (and hence, also religious) features means that these documents are increasingly seen as texts only, with little if any attention being paid to the physical and material qualities of these documents.

This combination of inflexible 'presentism' and positivism continues to choke the historiography of medieval Arabic documents into two modes of history: the apologetic and the polemic. In the former, documentary evidence is piled up as a retort to older Euro-centric charges based on narratives of lack (of capitalism, proper legal culture, etc.); in the latter, they are heaped together and brandished as weapons of a social history that constantly defends itself against the ubiquitous specter of older histories based on narrative sources.

\section{The scope of the paper}

One of the most problematic features of the traditional claim about the lack of archives is its undefined geographical and historical scope. Of course this helps to marshal the alleged absence as evidence for wider essentialist claims, but it also hampers any historical investigation with the burden of numerous teleological claims -like the failure to develop capitalism. The following essay will substitute for this stratospheric level of schematic generalization a micro-historical investigation of a few historical cases.

\footnotetext{
${ }^{4}$ For one example, see Sundelin's comment on papyri from early Islamic Egypt: "In comparison with literary sources $[. .$.$] the papyri and these other documentary materials$ offer an immediate and relatively unmediated window through which to view the early development of an Islamic society", see Sundelin, L, "Introduction: Papyrology and the Study of Early Islamic Egypt", in P. Sijpesteijn and L. Sundelin (eds.), Papyrology and the History of Early Islamic Egypt, Leiden, 2004, 1-19, 7.
} 
The micro-historical lens and historical specificity is more than a corrective to essentialist generalizations; the precise context in which documents were produced and transacted has a direct bearing on the social uses, and logic, of archival collections. Only by focusing on specific cases can we rescue the complexity and messiness of social practice and begin to uncover the practical logic of not only positive acts, but also that of those omitted, of absence as well presence -to grasp the significance not only of collection and survival, but also of dispersal and destruction.

Based on these cases, I hope to present a preliminary research agenda that reformulates the problem of medieval archives into an investigation of archiving practices. ${ }^{5}$

As we shall see, absence could be neither lack nor lamentable lacunae: certain absences were integral to the life-cycle of documents and archives; in other cases, the incomplete record was itself the result of deliberate and purposeful practices; and finally, some traces were intentionally incomplete. In such cases, social strategies extended beyond the legal traces they produced; limiting ourselves to these traces or assuming that they represent a complete and unmediated picture is arbitrary and misleading. Here, the historical trace is but one dimension of a larger world of practice; understanding its shape and the social work it does for its 'authors' is a necessarily wider investigation that requires reading different traces against one another, for the clues they provide about the wider strategies of social actors.

\section{The Uses of Documents}

In one of the earliest extant formularies, the 3rd/9th-century Egyptian al-Ṭahāwī began his guide for notaries with a theoretical discussion of the uses of documents. Here he explained that documents play a role in deterring future conflicts between parties of a legal transaction. ${ }^{6}$ Not only are documents presented as a resource

${ }^{5}$ In a sense, this formulation advances Chamberlain's point (albeit to the opposite conclusion): to think of medieval archives not just in terms of an observation about available source material, but to treat archives as a historical problem in and of themselves.

${ }^{6}$ Al-Ṭahāwī, Aḥmad b. Muhammad, The Function of Documents in Islamic Law: the Chapters on Sales from Ṭahāwì's Kitāb Al-Shurūt Al-Kabīr, J.A. Wakin (ed.), Albany, 1972. 
to be consulted in the event of conflict (and in this they are superior to oral testimony and witnessing, which are limited by the inevitable loss of memory and mortality, not to mention the mercurial dispositions and recollections of the living); the mere knowledge of their existence discourages individuals who wish to cast doubt on a past transaction. Al-Tahāwi could not have adduced this deterrent function if documents were not carefully preserved -indeed, his argument would have little traction if individuals did not generally understand the availability and uses of archives.

Țahāwì's astute insight onto the social lives of documents highlights the intricate ways by which they are embedded in wider social practice including the agency of social actors who strategically produced, preserved, and deployed documents in specific historical conflicts, real or imagined, current or anticipated. This ostensibly simple remark is also crucial to restoring documents to a wider context as one of several options for conflict resolution in medieval society. Here the recent work of historians of medieval Europe, who have begun (especially since the mid-1970s) to re-conceptualize disputes and dispute resolution is especially productive. This shifts the focus from law as a structural system of rules to law as a resource that consumers could make use of, as one of several strategies including force, arbitration, etc. ${ }^{7}$ Stephen White notes that court proceedings "sometimes constituted only a single stage in the often long and complex process through which conflicts were resolved". ${ }^{8}$ In some cases, parties "may have initiated action in court in order to pressure their adversaries to settle out of court, while in other cases disputants may have desired formal legal recognition for their extra-judicial settlements". 9

7 See the excellent review of historiography by Brown, W. and Górecki, P., "What Conflict Means: The Making of Medieval Conflict Studies in the United States, 19702000", in W. Brown and P. Górecki (eds.), Conflict in Medieval Europe: Changing Perspectives on Society and Culture, Aldershot, 2003, 1-35.

${ }^{8}$ White, S., "Pactum ... Legem Vinvit et Amor Judicium: The Settlement of Disputes by Compromise in Eleventh-Century Western France", American Journal of Legal History, 22 (1978), 281-308, 294. For the 'consumption of justice', see Smail, D.L., The Consumption of Justice: Emotions, Publicity, and Legal Culture in Marseille, 1264-1423, Ithaca, 2003.

${ }^{9}$ Wray, S.K., "Instruments of Concord: Making Peace and Settling Disputes Through a Notary in the City and Contado of Late Medieval Bologna”, Journal of Social History, 42 (2009), 733-760, 735.

Al-Qanțara XXXII 2, julio-diciembre 2011, pp. 389-434 ISSN 0211-3589 
Such insights underscore the highly contextual and indeed contingent nature of the legal record. Documents could be strategically used to officialize only particular aspects of a case or conflict, to render them legible in a particular way. But such situational use means that while they inscribed particular acts and agreements, these legal traces were purposefully selective and incomplete. In order to understand the work they performed for their users, it is necessary to restore them to a wider social -and necessarily extra-legal-context. For this task, documentary evidence needs to be supplemented with other sources that shed light on its specific social location and significance.

We begin with two cases that did not leave us documents today; unlike the majority of extant documents, these cases -both related in narrative sources- do not refer to property rights. Instead treat and establish more immediate, private, and personal rights and they are meant to illustrate Mamlūk subjects' deep investment in legal practice. Ironically, their ultimate disappearance reminds us that presence and transparency (or completeness) were not in and of themselves meaningful to medieval actors. Indeed, if such 'presence' potentially challenged to more meaningful processes of self-fashioning it could be dealt with as decisively as any 'positive' threat from an adversary.

In the mid-15th century, Bint Shamla, a Damascene Jewish woman converted to Islam, by using a legal subterfuge I have called 'singlegeneration conversion', she managed to maintain her children as Jews-and accomplished this through Islamic law. The subterfuge was based on claiming that her children had attained the age of majority at the time of her conversion; as adults, their religious identity did not automatically follow her own. When neighbors challenged this and brought her children before a Muslim judge, the latter ruled that they were legally Muslim-unless there was a shar ${ }^{\prime} i$ reason preventing this. At this point, Bint Shamla produced a critical document she had secured from the judge who had registered her conversion ten years earlier in Tripoli: the writ explicity established that her children remained Jewish, i.e. were unaffected by her religious conversion. The Tripolitan document was examined by the Damascene judge, who begrudgingly admitted its authenticity and conceded that it bound his ruling. True, this was a hilla (subterfuge), but its success and the deliberate foresight and purposeful anticipation with which Bint Shamla had procured and carefully preserved this writ bespeak her investment and trust in Islamic legal documents. 
Similarly, when a group of Toledan conversos arrived in Cairo in the 1440s and declared their intention to revert back to Judaism, a conflict erupted between the city's Rabbinate and Karaite Jewish communities, each seeking to enlist the Toledans among their ranks. Interestingly, both parties chose to conduct the conflict in Islamic courts. Both solicited several fatāwa from the judges of the different schools of Islamic law (madhāhib). And by strategizing around the contents of these fatāwa , the Karaite community was able to initiate their suit before the appropriate judge-whose school's position supported their claim thereby converting the Toledans to Karaite Judaism and recruiting them to their community. ${ }^{10}$

In both cases the deliberate solicitation and preservation of legal documents reveal that non-Muslim communities trusted Islamic law as a readily available and effective resource to be mobilized in social conflict-even in confrontations with members of another congregation over issues of internal religious identity.

This is all the more remarkable given that dhimmi privileges in a society like Mamlūk Egypt were secured through a quasi-constitutional tradition, the Pact of 'Umar. This legal tradition was a foundational document that spelled out non-Muslims' rights and responsibilities; it survived in a relatively stable form for almost seven centuries -and was periodically invoked and reinstated in specific situations of conflict and negotiation. Yet what is most remarkable about this durability is that dhimmi communities in many instances used legal documents, that is court-issued documents as well as fat $\bar{a} w \bar{a}$ solicited from muftiss, to secure rights above and beyond those spelled out in the Pact. In some cases, this involved direct violation of, or rather, subterfuges to get around, the strictures of the Pact ${ }^{11}$.

${ }^{10}$ Interestingly, the case is narrated in a Karaite historical account, which carefully reproduces the responsa of the different muftis (jurisconsults): Qișsat al-Ifranj [Story of the Franks], BL MS Or. 2538, fols. 73r-83r. For a discussion of the text and incident, see El-Leithy, T., "Coptic Culture and Conversion in Medieval Cairo. 1293-1524 A.D.", (Ph.D. Dissertation at Princeton University, 2005) chapter Nine; Rustow, M., "Karaites Real and Imagined: Three Cases of Jewish Heresy", Past and Present, 197 (2007), 35-74.

${ }^{11}$ For more on the Pact of 'Umar, see Cohen, M., "What was the Pact of 'Umar? A Literary-Historical Study", JSAI, 23 (1999), 100-157 and the studies cited in his review (esp. 100-5).

Al-Qanțara XXXII 2, julio-diciembre 2011, pp. 389-434 ISSN 0211-3589 


\section{Translating Georgian Property: Four Documents \& a Monastery}

As with the first cases of Bint Shamla and the Toledans, our next case involves documents related to dhimmi-s (now currently housed at the Greek Orthodox Patriarchate of Jerusalem), which worked to qualify the legal stipulations of the Pact of 'Umar. ${ }^{12}$ The first consists of a protocol of a hearing that took place before a Shāfi' $\overline{1}$ court in Jerusalem in March 1358. The hearing concerned an inspection or audit of the property of the Georgian community in Jerusalem (especially that of the Monastery of the Holy Cross) by a representative of the Mamlūk Treasury. This official had cited the Georgians to appear before the court, and in response, the head of the community, Abbot Ioane, appeared before the judge -and presented him with a series of historical decrees issued by Mamlūk sovereigns confirming the property rights of the Georgians.

The issue before the court was not new: the fiscal administration of non-Muslim estates was increasingly contested (and alternatively legislated) in the late Middle Ages, and especially under the Mamlūks. Here Ionae appeared before the Shāfi' ${ }^{1} \bar{j}$ judge, al-Umawì , and presented a documentary arsenal that was probably as accessibly stored as it was critically prized. Upon reading (and accepting) these decrees, al-Umawi issued his order to inspect the Georgian's property and the outcome appears to have been satisfactory to both the Georgians and the court.

But only a few months later, and in direct violation of the earlier inspection, the governor of Jerusalem expropriated 1.000 dirhams from the Georgians. This prompted the community to submit a petition to the Sublime Porte. From the phrasing and format of the sovereign response, it is clear that the petition was submitted to the Palace of Justice (Dār al-'adl) in Cairo, earning the Georgians a public audience with the sultan. Here the Georgians (or their official emis-

12 These two documents, along with numerous others confirming rights of property and protection by Mamlūk sovereigns, were preserved by the Georgians in their monastic archives for centuries after their production. It was only when the Georgian monastery was absorbed by the Greek Orthodox in the 19th century that these documents were taken over and integrated into the archives of the Greek Orthodox Patriarchate of Jerusalem (where they now reside). See Müller, C. and Pahlitzsch, J., "Sultan Baybars I and the Georgians -in the Light of New Documents Related to the Monastery of the Holy Cross in Jerusalem", Arabica, 51 (2004), 258-90 (edition in pp. 282-3), 261 and n. 8.

Al-Qantara XXXII 2, julio-diciembre 2011, pp. 389-434 ISSN 0211-3589 
saries) presented documents confirming their privileges-much like Ioane had seven months earlier to the Shăfi ${ }^{'} 1$ judge of Jerusalem. The evidence was apparently convincing, leading sultan al-Nāșir Hasan to give the order to compose his ruling. This was our document, a personally-addressed missive or mukattaba, in which the sovereign ordered the return of the expropriated funds. The document issued by the chancery was published in the form a long scroll-at a total length of $334.2 \mathrm{~cm}$, it consisted of 11 sheets of paper, each measuring roughly $35 \mathrm{~cm}$ in length, glued together. In a customary display of the sovereign privilege of waste, the first and second sheets are entirely blank and the spacing between the lines ranges between 10 and $11 \mathrm{~cm} .{ }^{13}$ As we shall see, the spacing between the lines was symbolic of the difference in rank between the sender and addressee; in this case, the recipient was one amīr Shihāb al-Dīn, an amīr of forty.

In the first document, Abbot Ioane apparently presented several documents: the most current were issued by one amīr Shahīd al-Dīn al-Nāșirī and by the reigning sultan al-Nāșir Hasan (ruled 748752/1347-51 and 755-762/1354-61). In addition, he also produced a much older document, a decree from the Ayyubid sultan al-Malik al-Kāmil dated 625/1228. Although this earlier Ayyubid decree is no longer extant, its contents are described in our document as including a significant clause, namely, that "the Dīwän al-Mawārith (the Treasury's Bureau of Estates) was not allowed to encroach on the estates of Georgian men or women". ${ }^{14}$

The witnesses' detail concerning their right of possessions is crucial: in addition to certifying their direct ownership of certain properties (e.g. the shops within the monastery), the witnesses also noted that the few extramural properties, had also been "under their possession [ fi-aydìhim, lit. under their hands] for a period over thirty or forty years" -i.e. from at least 729 or even 719 A.H. Perhaps this

${ }_{13}$ Sultani scrolls were often that impressively long. The earlier shāfi ‘'i court protocol, for example, measured $34.5 \mathrm{~cm}$ in length, i.e. about one of the eleven sheets of this scroll. Similarly, in the spacing between the lines, the contrast with the court protocol -where the lines are densely packed with only a couple of centimeters between them- is striking.

${ }^{14}$ My translation differs slightly from that offered by Pahlitzsch's, see Pahlitzsch, J., "Documents in Intercultural Communication in Mamlūk Jerusalem. The Georgians under Sultan an-Nasir Hasan in 759 (1358)", in A. Beihammer, M. Parani and C. Schabel (eds.), Diplomatics in the Eastern Mediterranean 1000-1500. Aspects of Cross-Cultural Communication, Leiden, 2008, 373-394, lines 10-11, pp. 381-2. 
gratuitous figure was included in order to establish their long-term possession which would facilitate subsequent claims to ownership.

The Georgians' charters of protection from the Estates Bureau are particularly significant given the immediate context of the document: in 755/1354 -only five years prior to the Georgians' law-suit- the Mamlūks introduced a critical edict targeting dhimmī-s. ${ }^{15}$ The edict reinstated the various stipulations of the Pact of 'Umar-from the distinguishing dress codes of non-Muslims, to the ban on their employment in the bureaucracy. Furthermore, it included several new clauses targeting converts to Islam. Here, the most relevant was that a dhimm $\vec{\imath}$ s personal conversion was no longer considered sufficient: his (or her) entire family now had to convert. In addition, converts were prohibited from forfeiting their inheritance from a dhimmi relative. Last but not least, the edict ruled that upon a dhimm $\vec{\imath}$ s death, his/her entire estate reverted to the Bureau of Escheats, until their heirs presented proof of their entitlement to a share-according to Islamic law. Upon presenting such documentation, an heir would receive his or her legal share; if the shares of the heirs did not add up to 1 , the Treasury was entitled to the remainder, as "residual heir". Where there were no rightful heirs, the entire estate would revert to the Treasury.

As I have demonstrated elsewhere, the first two clauses were a direct response to the abovementioned legal subterfuge, single-generation conversion, whereby a dhimmi $\bar{\imath}$ who decided to convert for fiscal or social reasons (e.g. to avoid the burden of the poll-tax, to seek promotion and social advancement, etc.) could do so while keeping the rest of his family as non-Muslim. This is precisely what we have seen in the case of Bint Shamla, the Damascene Jewish convert, who had maintained her children as Jewish. This ruse was accomplished through Muslim courts: the convert would appear before the same judge who officiated her own conversion, and claim that her children were all above the age of reasoning. As adults, the progeny were deemed independent agents who were responsible for their own religious affiliation. In an age before birth certificates and in a judicial

15 The edict is reproduced in al-Qalqashandī, A. b. 'Alī, Subh al-A'shā, Cairo, 191319, 13: 377-87. For the historical context and background to the edit, see Vermeulen, U., "The Rescript of al-Malik aș-Ṣāliḥ against the Dimmis (755 A.H./1354 A.D.)", Orientalia Lovaniensia Periodica, 9 (1978), 175-184. 
culture where women and children were often represented by male guardians and/or agents, establishing the age of the children was often simply a matter of presenting corroborated testimony, e.g. that of friends and neighbors. The act was complimented by the convert forfeiting her share in estate of a (dhimm $\vec{\imath})$ parent, thereby ensuring that the property devolved straight from (dhimm $\vec{\imath}$ ) grandparents to their (dhimmil) grandchildren -i.e. entirely bypassing the convert and remaining within the family and the original religious community. The ruse thus allowed dhimmi-s in medieval Egypt to reap the personal (and short-term) gains of conversion to Islam, without relinquishing their patrimony, both material and religious.

The edict targeted precisely those practices that enabled singlegeneration conversion: individual (as opposed to entire family) conversion, and the ability to forfeit one's share in an inheritance. It also served as an alibi for the Mamlūk state to insert itself within dhimmi communal affairs-primarily to extract wealth from these communities, but ultimately, such measures also worked to undermine dhimmi communal authorities. Before this edict, a Coptic estate without due heirs would have reverted to the Coptic Patriarch, or his local representative. ${ }^{16}$

The 755/1354 edict thus changed the rules of the game: it created pressure on family members to convert in order to retain their wealth within the family, now that the avenue of forfeiting one's share was closed. ${ }^{17}$ The economy of conversion was thus radically altered in the mid-8th/14th century.

Thus, the explicit reference in the Georgians' document to the Dīwān's encroachment on dhimmī estates is doubly significant: first, in historical terms, it is interesting that the Georgians were not only familiar with this claim by the Treasury, but had secured and carefully preserved exemption from it- almost a century earlier (1240s). Second, in terms of contemporary significance, the presentation and acceptance of the earlier protection as a royal exception clearly held enough authority to actively limit or qualify the more recent edict by al-Ṣālih. Indeed, in this sense, the audit of the Georgians' property represented an updating of the judicial record, by means of reactivat-

${ }^{16}$ Incidentally, this was the case for some baptized Jews in medieval Europe, for example, in Germany see Lotter, F., "The Scope and Effectiveness of Imperial Jewry Law in the High Middle Ages", Jewish History, 4 (1989), 40-1.

${ }^{17}$ It is worth recalling that direct inheritance was but one of several avenues for the devolution of property.

Al-Qanțara XXXII 2, julio-diciembre 2011, pp. 389-434 ISSN 0211-3589 
ing a decree from an earlier sovereign authority (the Ayyūbids) and making it current vis-à-vis the contemporary Mamlūk authorities.

Another interesting detail in the first (court-issued) document -and again in the form of a secondary mention of the content of a now-lost document- is the description of the rights of the Georgians. According to the earlier marsüms, the Georgian "monks and priests" were authorized to "continue according to their ongoing custom and venerable rules ['ādātihim al-mustamirra wa-qā'idatihim al-mustaqirra] in matters involving their awqāf and monasteries and churches" -adding the explicit injunction that "nothing should be demanded of them unjustly (without cause)". ${ }^{18}$

In his edition and commentary on the document, J. Pahlitzsch notes that the reference to Georgian $a w q \bar{a} f$ is unclear. He argues that it is "doubtful that the Georgians had transformed the property ... into Islamic waqf" preferring to read the term waqf as "analogous to Christian church property". ${ }^{19}$

Although this may be accurate, it may also be possible to suggest that rather than the imperfect correspondence of technical translation, what we are witnessing is a deliberate choice whereby Mamlūk authorities (first the sultanic/amiral authors of the decrees, and then the judicial authority who validated these documents and enacted them) were translating the Georgians' property into a category of Islamic law that would guarantee them both secure property rights and independent administration. In other words, the document represents a purposeful reclassification of the property in question, which aimed at granting the Georgians and their property the full protections of pious endowments - even if they were not technically registered as such.

A court mahdar from almost a century earlier (dated 664/1265) represents another earlier and clearer instance of such legal translation -this time, possibly sought out by the Georgians themselves. ${ }^{20}$ Here the deposition presented a classic suit between the Georgians and one Yūsuf al-Mashriqī, who was -briefly and vaguely- charged with hurting the monks. In the course of adjudicating the 'dispute', the judge

${ }^{18}$ My translations differs slightly from that of Pahlitzsch, see Pahlitzsch, "Documents in Intercultural Communication", lines 8-9, p. 381.

${ }^{19}$ Pahlitzsch, "Documents in Intercultural Communication", 374.

${ }^{20}$ Greek Orthodox Patriarchate, Document IV.A 218/2 recto (shahāda-mahdar) and verso (ishhād), dated 25 Dhū l-Qa'da 664/28 August 1266.

Al-Qanțara XXXII 2, julio-diciembre 2011, pp. 389-434 ISSN 0211-3589 
ordered numerous Muslim "just witnesses" to first verify and establish the extent and nature of the Georgians' monastic property. After establishing their knowledge of then-Abbot Luccas and his monks -no less than seven monks are mentioned by name, including one interestingly identified as al-shaykh Jaraj [= George]- who lived in the monastery, the witnesses outlined its specific possessions. Next, the witnesses identify the monastery's properties, including "the Rüm $\bar{\imath}$ endowment known as al-Qatamūn" as well as "Dayr al-Ka'kūl and its tower, which are also endowments [habis]".

It is in the following phrases that the property is carefully described in legally significant terms as "being since time immemorial and until the present [min qadìm al-zamān wa-hadìthihi] in their possession and ownership, under their administration and rightfully theirs [bi-aydīhim wa-hiyāzatihim wa-tașsarufihim wa-istihqāqihim]". In the second phase of classification, the witnesses establish that the property -once again identified as habiss, albeit without the Rümi modifier ${ }^{21}$ - was the site of their worship, where they celebrated their religious festivals. In other words, that the property was religious in function and usage (and not merely private property owned by the abbot or monks as individuals). In the final phase of translation, the witnesses return to the property's temporality and devolution, adding that it "did not leave their possession and ownership in any manner, or for any reason, but that it has been inherited [yatawärathünahu] by one group of monks from the other" in a process "overseen by one abbot after another".

In the next section of the disposition, the work of legal classification extends to the monastic community itself: here the monks are explicitly termed ahl al-dhimma not only emphasizing their subjection to the sultan's sovereignty to whom they "constantly paid reverence", but also implicating him by highlighting his reciprocal duty of protecting them. Here the witnesses go out of their way to highlight the position of the Georgian monks as obedient subjects not only of the reigning Mamlūk Baybars, but also of his "predecessor kings and sultans", for whose longevity and victory they have continually prayed to God.

Finally, a specific detail stands out, namely the witnesses' last testimony, whereby they assert that Abbot Luca and his monks had

${ }^{21}$ The designation as pious endowment [habiss] is repeated in a later section of the deposition, albeit without the modifier Rūmī (which may suggest that the first usage was less a categorical than a descriptive adjective for the property). 
"served Muslims by providing them hospitality and shelter" within the monastery, especially "in times of hardship" when they provided "refuge to Muslims within their walls and protected their children and property" from the Mongol enemy. This section, as well as the preceding demonstration of the monks' political loyalties, was perhaps especially necessary, as Müller and Pahlitzsch explain, given the diplomatic and political context of the period, when relations between the Mamlūk state and Georgia were at best tense, especially in the immediate wake of the Mongol attacks only a few years earlier. ${ }^{22}$

Only after these various sections of descriptive validation did the witnesses finally turn (in less than half of a single line -out of a total of eleven) to the alleged reason for the document's production: one Yùsuf al-Mashriqī's infractions against the Georgian property. Almost as an after-thought, the witnesses assert that Yūsuf was, indeed, "harming [yu'dhì] the monks and causing them damage [ darar] and

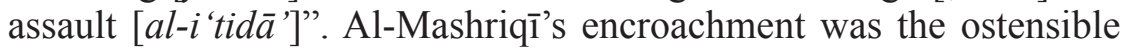
occasion for the entire court deposition, the alibi for the witnesses' detailed audit and description of the monastery and its monks. And yet the description is vague, almost hurried; as Müller and Pahlitzsch note.

In [the judge's] summoning of witnesses (ishhād), neither the evidence presented by the opposing side nor the substance of the conflict are elucidated. ... [O]ne has the impression of a limited dispute, perhaps concerning the rights to certain sections of the land used by the monastery. ${ }^{23}$

Again, this may well be the case. But it is also possible to consider the incident as a case of a performative suit, whereby the monks exploited a minor (or even imagined) infraction, in order to appear before the Muslim judge, who would then be expected to order the precise audit of the monastery and its properties, thereby occasioning their translation as a recognizable endowment. In other words, the actual law suit here (be it with or without the collaboration of the offender, Yūsuf al-Mashriqī) was a performative procedural fiction aimed at producing the court deposition.

${ }^{22}$ Müller and Pahlitzsch, "Sultan Baybars I and the Georgians", $270 \mathrm{ff}$.

${ }^{23}$ Müller and Pahlitzsch, "Sultan Baybars I and the Georgians", 270. The authors also note that "there is no hint in these documents of the subsequent dramatic turn of events ending in the monastery being turned into a Sufi convent and the murder of Abbot Lucas". 
The witnesses' appeal to antiquity and continuity, as well as the charged terms signifying ownership and use once again suggest a deliberate strategy of legal translation, their speech-acts rendered the Georgian community and their possessions legible to Islamic courts.

If this was the case, then the lengthy and precise audit of the monks and their property may well have been ends in themselves. In such cases, legal suits could be but one part of a wider social strategy. Documentary trail would only include specific and deliberately sought traces of the strategy, not its complete image. Here, the ultimate goal was (i) the legal translation of the monastery and its properties into terms and categories of Islamic law, which would (ii) allow their inscription in a legally recognizable and valid statement of right. This string of legal modifiers of right/possession, religious function and temporality represent the substance of the legal translation: in using these weighty terms, one after the other, the witnesses were in effect completing a checklist that rendered the monastery's property legible as waqf to the Muslim courts. Finally, the legal act both produced a (documentary) resource to be preserved, in the event of future conflict and modified the political and economic reality of the monks by altering their legal inscription (representation).

This reading is perhaps supported by another document, issued six months later (30 Muharram 665/31 October 1266), wherein the Mamlūk sultan, Baybars, in a personal missive [mukātaba], instructs an amir to uphold the rights (to renew the orders of protection and privilege) of Abbot Lucas, his monks, as well as the villages belonging to the monastery, al-Qațamūn and Dayr al-Ka'kūl. ${ }^{24}$ In other words, the sultan's missive takes the categories and terms that were legally translated in the court-mahdar a few months earlier, as operative and valid; and based on this, the sultan issues his order confirming rights and protection. (Thus, the sultanic missive refers to the monastic property and villages simply as "its endowments [awqāfihā]" suggesting that the Georgians' property had become validated as pious endowments in the eye of Islamic courts; the term waqf Rümi, wich was used once in the earlier court document, does not appear

${ }^{24}$ As with the abovementioned Georgian documents, this missive is currently held in the archives of the Greek Orthodox Patriarchate of Jerusalem (under reference number IV.A 218.2). It was edited, as cited before, by Müller and Pahlitzsch, "Sultan Baybars I and the Georgians". 
at point in this later missive.) Thus the court document (and the legal translation it effected) was a pre-requisite for the monks' appeal to, and securing of, the sultan's political and administrative recognition of the Georgians' property rights. ${ }^{25}$

This strategic act of legal translation, purposefully sought out and officialized through a dramatic suit with al-Mashriqī, raises the question of the Georgians' familiarity with Islamic law and courts. The manner by which the court and sultanic documents relate to one another is also significant: it represents an instance where Mamlūk sovereignty was enunciated, where judicial and political authorities interacted and how the categories of one were readily legible to, and acceptable by, the other. ${ }^{26}$

Finally, the last lines of Baybars' missive state that "After execution [of its content], the missive shall remain in [the Georgians'] hands" providing a final clue about the subsequent fate of the document in the Georgians' archives -even when the main property it referred to (the Monastery of the Holy Cross) was expropriated and converted into a Sufi convent. ${ }^{27}$

\section{St. Catherine's Fatāwā Collection: From Object to Practice}

Just as the Georgian monks' carefully stored and preserved their documents of rights -both court-issued documents and official decrees/missives from political authorities- their monastic counterparts at the Greek Orthodox monastery of St. Catherine's in Sinai, similarly compiled an impressive library of documents that they used not only to defend their rights from the depredations of desert Bedouins, but

${ }^{25}$ Müller and Pahlitzsch, "Sultan Baybars I and the Georgians", 270. Here I depart from the reading and suggestion offered by Müller and Pahlitzsch, who argue that the ultimately Georgian Monastry "was not itself termed a pious foundation" i.e. continued to be considered waqf rūmī, Müller and Pahlitzsch, "Sultan Baybars I and the Georgians", 274.

${ }^{26}$ Both the 1260s and the 1350s pairs of Georgian documents have a similar pattern of an initial court-issued document quickly followed by an official state missive. It is possible that this was an established pattern. For a discussion of the relationship between Islamic legal and Mamlūk political authorities in dhimmī policies (and especially regulation), see El-Leithy, T., "Sufis, Copts, and the Politics of Piety: Moral Regulation in Fourteenth-Century Upper Egypt", in R. McGregor and A. Sabra (eds.), The Development of Sufism in Mamluk Egypt, Cairo, 2005, 75-119.

${ }^{27}$ See Müller and Pahlitzsch, "Sultan Baybars I and the Georgians", 270-4. 
also to inscribe themselves onto the Mamlūk legal terrain. St. Catherine's monastic library contains dozens of administrative 'charters' of protection issued by political sovereigns, the Fāțimids, Ayyūbids, Mamlūks and Ottomans. Furthermore, it includes numerous deeds, primarily waqf deeds of property established as pious endowments to benefit the monastery and its monks. But perhaps the most interesting group of documents in this Sinai monastery consists of scores of fat $\bar{a} w \bar{a}$, solicited and carefully preserved by the monks.

I will argue that this collection of fatāwā constitutes an invaluable -and hitherto invisible- archive of the monastic community. First a word about its 'invisibility' which ultimately derives from, and thus urges us to rethink, the traditional paradigm according to which medieval Arabic documents have been studied. This approach has focused exclusively on legal documents issued by Muslim courts. In this sense, scholars have continued to seek -only to lament the absence of- certain forms or things; accordingly, the archive was reduced to, and reified as, a static, unchanging collection of legal deeds. As we have noted, such a definition is restrictive, its inflexible idealism abstracts and schematizes legal practice and eviscerates it of its necessary social and historical dimensions.

Instead, we should investigate the social logic of archival strategies -involving anything purposefully stored with the expectation of future retrieval and use to establish rights- and the role such instruments and practices played in social competition and group formation, survival and reproduction. In this redefinition I hope to replace the stratospheric snapshots of structuralism, where the entire legal system is a static and codified set of rules. By contrast, the focus on strategies is meant to acknowledge ongoing developments and change and reintroduce agents whose strategies exhibit a practical sense and social logic.

Bourdieu insight regarding the study of households and families is equally productive when applied to religious communities, like St. Catherine's monks, as a social group: here too, we must investigate

the specific logic of strategies which groups use to produce and reproduce themselves, that is, to create and perpetuate their unity, and thus their existence as groups, which is the condition of the perpetuation of their position in the social space. ${ }^{28}$

${ }^{28}$ Bourdieu, P., "From rules to strategies", in In other words: Essays towards a Reflexive Sociology, Stanford, 1990, 74.

Al-Qanțara XXXII 2, julio-diciembre 2011, pp. 389-434 ISSN 0211-3589 
In both instances, archival resources functioned as both the repository of various social and legal strategies and a practical tool used for group formation, maintenance, and reproduction.

Applying this methodological insight allows us to discover a series of documentary collections, which have been treated -and, which socially behaved- like conventional archives ${ }^{29}$. An excellent example of such a collection is the cache of fatāwa $\bar{a}$, or legal responsa, issued by Muslim muftis (jurisconsults) to questions posed by the monks of St. Catherine's Monastery in Sinai. Since the responsa were not legally binding and merely stated the position of the school of law on a particular issue, they served as an educational tool. Based on the results they received from the different muftis, the monks could select the school most advantageous to them, and then bring a lawsuit before a judge of that $\mathrm{school}^{30}$.

In one example, the monks solicited fatāwa from the muftis of different schools of law on the permissibility of restoring dilapidated parts of the monastery. What is interesting is the way in which the question was phrased: a long preamble describing the monastery and the specific section in need of repair concludes with the remarkable -and gratuitous- mention that the monastery's location in the middle of the desert makes it a resting place for all kinds of travelers including Muslim pilgrims on the way to $\mathrm{Mecca}^{31}$. Suddenly, the wall in need of repair is no longer just part of the edifice of a non-Muslim house of worship which, given its dedication to propagating a religion other than Islam is usually denied the right to perform renovations, since these would technically amount to giving aid and comfort to non-Muslim faiths. The wall in question now with discursively buttressed by the carefully worded question serves to protect, not only the Christian monks but also any travelers including Muslims pilgrims, from dangers like wild animals, bedouin raids, etc. Once again,

${ }^{29}$ Only recently have scholars begun to uncover the ways by which fatāwa were integrated into the judicial practice. For an excellent example such analysis, see Powers, D., "Kadijustiz or Qāộ̄-Justice? A Paternity Dispute from Fourteenth-Century Morocco", Islamic Law and Society, 1 (1994), 332-366.

${ }^{30}$ This latitude was available to litigants on issues (matters) where the Mamlūk state had not officially instituted a specific madhhab. For more on Mamlūk legal pluralism, including a discussion of numerous topics that the Mamlūks had assigned to specific madhhab, see Rapoport, Y., "Legal Diversity in the Age of Taqlìd: The Four Chief Qādīis under the Mamluks", Islamic Law and Society, 10 (2003), 210-228.

31 St. Catherine's Monastery Library, Fatāwā Collection, MS Fatwa no 225. 
the fatwa modified the explicit strictures of the Pact of 'Umar, perhaps another reason why it was carefully sought and meticulously preserved.

Despite its brevity, the fatwa $\bar{a}$ 's significant -and purposeful- description of the monks' relationship with Muslim travelers echoes what we have seen in the near-contemporary Georgian monks' court deposition (mid-8th/14th c.). In both instances, the dhimmi communities were clearly positioning themselves within those categories of Islamic law that would secure the privileges they sought. In both instances, a careful historical narrative including specific details and crafted in a particular language, achieved a form of legal translation.

The responsa questions address the temporal affairs of the monastery, especially its relations with other social groups. The most important relations were the potentially conflictual, if not violent, encounters with neighboring Bedouins. The latter were the subject of numerous sultani decrees protecting the monks/monastery and threatening punishment and fines should the nomads attack the monastery's orchards or vines, etc.

A somewhat later example, from the Coptic community in the late-16th century demonstrates the degree to which such strategies of appeal to Muslim courts and muftis -and careful use of Islamic legal terms and concepts- could be used not only in relations with the state and Muslim groups, but also intra-dhimmi and intra-communal conflict. In 1597, the Coptic patriarch Ghubriyal VIII (15871603) signed an agreement of unification with the Roman Catholic Pope. Among the first steps towards unification, he decided to apply the Gregorian calendar in Egypt. The decision was met with serious hostility by the Coptic community and one of the more significant responses came from a group of Coptic lay notables (archons) who petitioned Muslim religious scholars for a fatwā regarding this Patriarch who "broke the laws of the Church". Again, what is most significant here is the phrasing of the question: "What is your opinion of the leader of one of the Christian communities who tries to force his community to break its Church's venerable laws regarding fasting and festivals [given that these were based on the calendar]? If the members of the community complain to the political authority (waliyy al-amr), would he force them to obey their leader in this transgression or would he command the leader to apply the customary traditions of the Church?" 
As Magdi Guirguis notes, the carefully composed question practically determined the response of the muftis. ${ }^{32}$ It was as if the questioners had looked up the Patriarch's charters of appointment by the state and deliberately described his actions in terms of violating its clauses. Indeed the stress on the Patriarch's "transgression" as a clear flouting of age-old custom clearly provoked the mufti's suspicion and outrage, especially in matters of worship and ritual, of bid' $a$ or "(heretical) innovation". As in the Georgians' documents, antiquity and continuity were strategically used albeit to the opposite ends: to highlight the transgressions of the Patriarch. Furthermore, the secondary question implicated both religious and political authorities in so far as they considered themselves guardians of venerable traditions and to the degree that they saw religious sedition as a communicable social disease, i.e. one that threatened the body politic at large. ${ }^{33}$

In view of their legal nature, and the long-standing custom of treating fat $\bar{a} w \bar{a}$ as prescriptive and doctrinal religious sources, the presence and value of these fatāw $\bar{a}$ have traditionally eluded social historians. But at least in the context of Mamlūk legal and notarial culture, where soliciting fatāw $\bar{a}$ was an integral stages of the judicial process, these documents now call for a reexamination as both resources and traces of social strategies. By analyzing them in both their archival context, i.e. in relation to other documents solicited and stored by St. Catherine's monastery, as well as their socio-legal worlds (i.e. the manner by which they were used in specific legal cases to advance and protect claims to rights and capital). We need to ask, for example, why certain questions were asked more than once, to different muftis, or with slight variations. Knowing the Mamlūk context of legal multiplicity and the ways in which subjects, especially dhimmīs, strategized around judicial difference, we may now not only restore this fatw $\bar{a}$ archive to the conditions of its production and development, but also appreciate some of the ingenious

${ }^{32}$ Guirguis, M., "The Organization of the Coptic Community in the Ottoman Period", in N. Hannah and R. Abbas (eds.), Society and Economy in Egypt and the Eastern Mediterranean 1600-1900. Essays in Honor of André Raymond, Cairo-New York, 2005, 206-207.

${ }^{33}$ The Toledan conversos had capitalized on the same forces in their earlier conversion tactics in mid-15th-century Mamlūk Cairo: here, the state was similarly concerned with intra-Jewish affairs. For a discussion of the concept and term bid 'a in dhimmī legal and moral discourses, see El-Leithy, "Coptic Culture". 
uses to which it was put. At this point, we may now move on to inquire about details: How did knowledge about Islamic law and judicial practice about the monastery circulate as the document came to be drafted? Whose idea, for example, was it to introduce the question regarding renovations, with an incidental but strategic reference to Muslim pilgrims receiving customary hospitality of food and shelter? The duties of the Muslim notary, who drafted the document upon a litigant's request, were sometimes described in formularies and often include giving counsel to his clients not only regarding the documents he was commissioned to produce, but also regarding legal advice. Did notaries play this role of legal arbitrage or cultural translation?

The other candidates for this critical work of legal translation and inscription are the muftis. Here the biography of a 9th/15th-century mufti may provide a clue: the biographer notes his illustrious career, explaining that his fame as a mufti led people to seek him out and depend on his word [sar al-itimād 'alayhi fí l-fatāwa ] derived from his "excellence, succinctness [precision, directness] and his awareness of the goals of questioners [maqāssid al-sa'ilinn]". ${ }^{34}$ Here the mufti's work -and popularity- consisted of much more than his knowledge of the law; it was explicitly related to his appreciation of, and sympathy for, the predicaments and aims of those who appeared before him. After all, as we have seen, a mufti's answers had not only immediate and direct consequences (the physical protection of the otherwise defenceless monks), but also long-term cultural processes of representation and authority (as with the archons' undermining of the "errant" Coptic Patriarch).

A final note on the effects of legal discourses and practices on the constitution of the social, in this case, the monks as a group. For

groups existed both in the objective reality of established regularities and constraints, and in representations, and also in all the strategies of bargaining, negotiating, etc, aimed at modifying reality by modifying its representations. ${ }^{35}$

Legal and archival practices work on the same register as Bourdieu's "strategies of bargaining", for they partake of both objec-

${ }^{34}$ Sakhāwī, Muhammad b. 'Abd al-Raḥmān, al-Daw'al-lāmi ' li-ahl al-qarn al-tāsi ', Beirut, 1966, 7: 27-8 (no. 56).

${ }^{35}$ Bourdieu, "From Rules to Strategies", 75.

Al-Qanțara XXXII 2, julio-diciembre 2011, pp. 389-434 ISSN 0211-3589 
tive conditions and schemes of representation and again, controlling one via the other.

As these dhimmī archives testify, both waqf and fatāwa were invaluable as strategies that were crucial to dhimmi communities' social reproduction. But both practices also involved strategies of self-representation regulated by Islamic law.

But law is not only externally regulative, but also internally constitutive, i.e. it is not simply a neutral resource that dhimmis could avail themselves of, without being gradually changed through such practice. In other words, to fully appreciate the social and cultural significance of these dhimmi archival collections, we must also begin to ask about the long-term effects of this use of -indeed dependence on- Islamic law, i.e. to study how legal acculturation gradually affected the constitution of these dhimmi communities. If the affairs of dhimmī households and communities were increasingly being negotiated in Muslim courts and through Islamic legal instruments, then the very survival of these Christian communities until today was not only made possible through their legal and archival strategies; these collections also constitute the evidence of the acculturation of nonMuslim communities to Arab-Muslim culture.

\section{A Witness' Journal \& the Notarial Culture of late-Medieval Damascus}

A serendipitous witness to the legal and notarial culture of Mamlūk urban society - to the documentary fabric that sustained and facilitated medieval life- survives in a recently edited chronicle, Shihāb al-Dīn Ahmad b. TTawq's al-Ta 'lī ${ }^{36}$ As the editor notes, the single autograph manuscript was handwritten in a singularly dense style, as if the author sought to make full use of every inch of paper at his disposal. This was all the more crucial given the author's modest background and limited means: Ibn Țawq, a first-generation migrant to Damascus, cobbled together his meagre income from a variety of sources: in addition to farming (he owned and planted small orchards in his hometown village of Jarud near Damascus); he occasionally

${ }^{36}$ Ibn Ṭawq, Aḥmad b. Muḥammad, al-Ta 'līq, yawmīyāt Shihāb al-Dìn Ahmad ibn Tawq, 834-915 h/1430-1509 m, J. al-Muhāìir (ed.), Damascus, 2000-06.

Al-Qanțara XXXII 2, julio-diciembre 2011, pp. 389-434 ISSN 0211-3589 
worked as an agricultural inspector and surveyor; he rarely got work as a copyist of manuscripts, and finally and perhaps most steadily, he worked as a professional witness (shāhid) and notary (muwaqqi ${ }^{\circ}$. Ibn Tawq's text is a fascinating and detailed account of everyday affairs: a personal journal of singular intimacy and detail, providing a rare window onto the author's domestic and private life; a meticulous accounting of his daily spending; and a candid diary of the many legal transactions he performed in his capacity as notary-witness.

It is this last feature of al-Ta 'li $q$-the chronicle as a detailed log of a notary's professional calendar- that represents an invaluable register of Mamlūk documentary culture. For our purposes, Ibn Țawq's detailed description of the various legal acts he witnesses, drafts contracts for, or even hears abouts affords unprecedented details both of legal procedures and the social practices in which they are embedded.

The question of Ibn Tawq's intentions for his composition remains unclear; stated differently, the author did not limit himself to the familiar conventions of contemporary genres. While his journal often reads like a chronicle -with very local constraints and interests- at other times, the author obsessively records his daily accounting in a manner that resembles an account book. Thus we encounter his every purchase and payment from daily foodstuff shopping to tips for a midwife who delivered his child. ${ }^{37}$ And while he was, like other minor 'ulama' 'enmeshed in an elaborate web of gift giving, Ibn Țawq reveals the economism behind such symbolic rituals by assiduously noting the cost of every gift, e.g. the measily 5 dirhams' cost of cakes and chickens from his village, that he sends to his patron, Shaykh Taqiyy al-Dīn b. Qāḍī 'Ajlūn. ${ }^{38}$

The question of how representative Ibn Tawq was need not detain us here. Rather than mining his journal for quantitative data, our aim here is to merely use his detailed text as a window onto Mamlūk notarial culture - to survey both the kinds of practices and cases that appeared before him and, especially, those aspects of legal arrangements that did not make their way into the documentary traces during a single year (887 AH/1481-2 AD). This survey is necessary qualitative and is intended to help us map the social and legal terrain, rather than grantity and measure its specific features.

${ }^{37}$ Ibn Ṭawq, al-Ta'lī $q, 144$.

${ }^{38}$ Ibn Ṭawq, al-Ta'lìq, 181.

Al-Qanțara XXXII 2, julio-diciembre 2011, pp. 389-434 ISSN 0211-3589 
Of about one hundred and two legal cases that Ibn Tawq describes in the first complete year covered by his journal (887 AH) -the majority in which he acted as a witness and/or notary- by far the single most frequent type of case or document issued related to income derived from pious endowments, at least 28 cases. In most cases, these documents were drafted in the case of one scholar receiving -or buying- a salaried position, or a share thereof, from another scholar. Since appointment to such stipendiary positions was inherited and traded, and given the preponderance of pious endowments (especially religious foundations) in late-Mamlūk cities like Damascus and Cairo, the documentary trail produced by such daily acts was dense and elaborate. Furthermore, such cases were seldom straightforward cases of transmission: venality was rampant, but in addition to sale of office, the price that even a fraction of a job like reciting the Qur'ān at a madrasa or endowed funerary complex was often enmeshed in other transactions, most notably credit.

Thus, for example, on $20 \mathrm{Rabī}^{`}$ I 889/17 April 1484, Ibn Țawq himself nazala (literally, descended) from his jobs at the Halabiyya madrasa -the imāma, sermon-preaching (khițāba) and Qur'ān recital of the Chapter of the Cave every Friday night- to one 'Alā' al-Dīn b. al-Qattān for the handsome sum of 50 ashrafi gold dinars. Present at the exchange, which took place at sunset that day, was Ibn Tawq's patron, who lends him 10 ashrafis. Ibn Tawq then turned to Shams al-Dīn Muhammad Zahlaq, a merchant, and "lent it [i.e. the 10 ashrafis] to him five times over, such that it became a debt of 50 . [Zahlaq] then loaned it [again, the 10 ashrafis] to Ibn al-Qatțān five times, such that it became a debt against Ibn al-Qatțān to him. Then the latter handed it to me five times over -instead of a direct nuzul. So let that be known...". ${ }^{39}$ Here Ibn Tawq used the occasion of office devolution to introduce one of the most classic subterfuges (hiyal) for lending with interest. ${ }^{40}$ Thus this case was also part of another significant cluster of cases, which involved lending money (in most cases, using elaborate hiyal to charge interest).

39 Ibn Ṭawq, al-Ta'līq, 350.

${ }^{40}$ On hiyal as a genre, see Horii, S., "Reconsideration of Legal Devices (Hiyal) in Islamic Jurisprudence: The Hanafis and their 'Exits' (makhārij)", Islamic Law and Society, 9 (2002), 312-357. 


\section{Elliptical Clues: 'May it be Known', But Not Recorded}

Indeed, in numerous cases, Ibn Tawq closes his description of a transaction with the seemingly formulaic phrase, "And (so) let that be known (fa-li-yu 'lam dhälik)", as if to remind himself of the event or the need to record it. But in most cases, he does not use the formula; upon closer examination, it appears that the phrase served to highlight particular kinds of legal acts, ones that had critically important backgrounds. Take for example, the wedding contract concluded on the 27 Dhu l-Hijja 886/16 February 1482, when Ibn Tawq along with four shaykhs visited the house of shaykh Badr al-Dīn b. Nabhān to witness the marriage of the latter's daughter. Our witness's writeup of the event -his own personal archive, as it were, of the circumstances and background of the transaction-assiduously records not only the handsome amount of the marriage gift (30 ashrafi gold dinars) but also the numerous conditions the host and father-in-law, Ibn Nabhān, stipulated of his new son-in-law. The groom vowed to not take any concubines (la yatasarrā) or take another (i.e. third for this was his second marriage) wife; similarly, he undertook not to relocate his first wife ("the old one") into the new residence of his second wife. And while Ibn Tawq carefully marked the sadāq amount as "payable upon demand (hallat ${ }^{a n}$ )", he concluded the entry by noting that they deferred receipt of the entire marriage gift as per their agreement. ${ }^{41}$

In addition to revealing the preferences of the bride and her family -and their power to translate these preferences into legally binding clauses - the description provides us a rare window onto the background and setting of a legal negotiation. Thus the generous-unpaid amount of the marriage gift emerges as more than an expression or testimony of the bride's familial honor: the fact that the amount, and especially a large sum as 30 ashrafis, was payable upon demand constituted a monetary check on the groom's behavior. For now, his failure to comply with the contractual obligations (regarding concubinage, residence, etc.) would not only mean that his wife would become automatically divorced, but also that she would be able to demand her full marriage gift on the spot and thus potentially bankrupt her husband. In fact, while certain clauses were explicitly listed

${ }^{41}$ Ibn Ṭawq, al-Ta 'līq, 1: 121.

Al-Qanțara XXXII 2, julio-diciembre 2011, pp. 389-434 ISSN 0211-3589 
in marriage contracts such as this one, the increasingly prevalent practice of "due-debt șadāq" practically meant that grooms were increasingly bound by monetized obligations to their wives, something that invariably altered relations of power between spouses ${ }^{42}$.

What is striking is that in almost every case, Ibn Tawq provides extra-documentary, indeed extra-legal, details, from the physical location of the deal or contract to the precise list of those present and even their physical disposition and emotional state. These details give us a vivid impression of what Ibn Tawq (and his contemporaries) considered meaningful. Here the extra-legal details were crucial aspects of the legal act; and the event was necessarily more than what was officially recorded in the documents produced.

In some cases, those additional details were not simply the setting or ritual of the deal but integral aspects of the concluded contract. Take, for example, the ostensibly simple rent contract concluded on 2 Muharram 886/3 March 1481 between one 'Abd al-Qādir the Merchant and Ibn TTawq's patron, Ibn Qāḍ̄ 'Ajlūn, for an oven (furn) and the first floor above it. The official document included the period (one year) and rental amount (40 silver dirhams payable at the beginning of every month). But Ibn Tawq also adds that along with the official rent, the renter had also agreed to provide free of charge the baking needs of the shaykh's household, of bread, eggplant, and meat. ${ }^{43}$ The additional obligation of the renter seems like an informal gift to the esteemed shaykh who attended (and perhaps, blessed) the contract by signing. While it does not significantly alter the substance of the agreement, the detail provides invaluable insight to the texture of the agreement -indeed, of Damascene legal culture in general, where the hallowed presence of an esteemed shaykh was not only deemed worth free baking for his household, but also considered noteworthy by our witness. In short, the account succinctly describes an instance of converting the shaykh's symbolic capital into a monthly fiscal obligation. That the arrangment was not a singular or exceptional case is

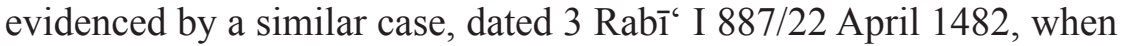
Ibn Tawq similarly witnessed the rental of the furn for the remainder of the year (i.e. ten more months) for a monthly rental of 60 dirhams.

${ }^{42}$ See Rapoport, Y., Marriage, Money and Divorce on Medieval Islamic Society, Cambridge, 2005, especially chapter 3 .

${ }^{43}$ Ibn Ṭawq, al-Ta'līq, 40. 
Once again, the account adds that the renter agreed to provide "baking needs and eggplant and meat for the shaykh's household". ${ }^{44}$

In other cases, Ibn Tawq's account provides other kinds of detail that did not make into the official contract -where the erasure or occlusion was deliberate and purposeful. A few months after the first oven rental, Ibn Tawq was part of a loan that he dutifully records, albeit somewhat elliptically. On Saturday 9 Shawwāl 886/30 November 1481, Ibn Tawq received 3.000 silver dirhams from Najm al-Dīn al-Ṭarābulusī, on behalf of Taqiyy al-Dīn al-Juhaynī, as a loan payable 26 days later. The promissory note, however, was made for 79 ashrafi gold dinars. ${ }^{45}$ Thus ends the brief notice in Ibn Tawq's journal. This transaction- which, again, would have left, in the official legal record, only an I-owe-you or a quittance for 79 ashrafis- is an interesting case of an interest-bearing loan: the gold dinar amount actually converts to no less than 4.108 dirhams (at exchange rate of 52 dirhams/ashrafi), meaning that the creditor charged an exorbitant 1.108 dirhams in interest, i.e. about $36.9 \%$ or about $1 \%$ per day! Here it is clear that Ibn Tawq was engaged in a legal subterfuge (hìla shar 'iyya), whereby the use of different currencies was intended to mask the interest charged and thus evade anti-usury law.

Almost a year later, on 12 Shawwāl 887/23 November 1482, Ibn Tawq was party to yet another elaborate legal charade intended to mask an interest-bearing loan. Here, our witness and his relative, Fātima bint Khātūn, met for him to first purchase a set of textiles from her for 2.000 silver dirhams; in the same setting, he resold the same goods to her for 2.400 dirhams payable one year later. ${ }^{46}$ Here the interest was $25 \%$ per annum; it is unclear whether the lower interest rate charged was because Fātima was his close relative, who was also engaged with him in other financial transactions (e.g. they jointly owned agricultural land in their home-village of Jawd). In any case, once again, the documentary record, would have necessarily provided an incomplete picture of the transaction -and deliberately so.

44 Ibn Ṭawq, al-Ta'lìq, 152.

${ }^{45}$ Ibn Ṭawq, al-Ta'līq, 94.

${ }^{46}$ Ibn Tawq, al-Ta $l \bar{l} q, 198-99$. In a similar case a couple of years later (889 AH/1483 AD), Ibn Ṭawq notes the receipt of 20 ashrafis -and drafts a promisory note for 1,200 dirhams payable ten months later. Here, the interest rate came to about $15 \%$ (ibid., 347).

Al-Qanțara XXXII 2, julio-diciembre 2011, pp. 389-434 ISSN 0211-3589 
In numerous cases, Ibn Tawq's use of the elliptical phrase, "[So] let that be known (fa-li-yu lam dhälik), highlights precisely the kind the crucial extra-legal details that would render the official trace not only incomplete but practically misleading. The cases bearing this notation all took place during a period of less than two years (the calendar years of 886 and 887) -and may easily be multiplied from Ibn Tawq's journal. ${ }^{47}$ For our purposes, these examples demonstrate that any expectation of direct correspondence between documentarylegal sources and social practice is necessarily misleading. Social actors, including those legal professionals like Ibn Ṭawq and his more illustrious patrons, constantly deployed legal resources in innovative and self-serving ways.

Analyzing Ibn Tawq's text reveals an invaluable methodological insight about the relationship between social practices (events) and their attendant documentary evidence (trace), namely, the prevalence and importance of those extra- and para-legal events that were intentionally kept out of the record. These methodological lessons extend beyond the details and content of his special transcript: our witness provides an astute directive to re-examine our tacit premises and the concomitant ways by which we use documents to reconstruct social history.

Such practices not only caution against positivist readings of legal documents, but also remind us that those seemingly stable ethical scruples that some 'ulam $\bar{a}$ ' voiced against legal subterfuges were not always shared by all members of the religious and legal establishment.

Indeed to accept the familiar moral fulminations of critics like Ibn Taymiyya or Ibn al-Qayyim against the corrosive effects of hiyal is to forget that these commentaries were specific claims of particular 'ulam $\bar{a}{ }^{48}$ While they may have promoted themselves as the sole

47 Of course, other cases-including the oven rentals and both interest-bearing loans cited above- did not include the phrase, although they clearly featured legal subterfuges, where the official documents produced were necessarily incomplete. For examples of the phrase used, see Ibn Țawq, al-Ta 'li q, 84, 121, 124, 125, 127-8, 131-2, 132, 134, 138, $139,140,146,148,149,150,155,156,156-7,177,182$, and 189.

${ }^{48}$ For al-Bukhārīs' denunciation of hiyal, especially in the Hanafi school, see Brown, J., The Canonization of al-Bukhari and Muslim: the Formation and Function of Sunni Hadith Canon, Leiden, 2007, 73. For Ibn Qayyim al-Jawziyya's discussion, see his I'lam al-muwaqqi'in, Cairo, 1374/1955, 3, 252ff. For Ibn Taymiyya's attempt to reform hiyal related to divorce and marriage, see Rapoport excellent analysis (Marriage, Money, chapter 5). 
custodians of the Law, it is to swallow their ideology to extend that vision to society at large, or even the entire 'ulam $\bar{a}$ ' establishment. Such tendencies betray the traditional scholarly preference for prescriptive sources which marginalize the world of social practice to the point of erasure, either by deferring to the vision of jurisprudential sources (fiqh) or, in more recent documentary studies, by adopting a restrictive, textual reading of legal documents $-\mathrm{a}$ reading that necessarily occludes their crucial extra-legal setting. Behind -or alongside - the familiar, loud and magnetic refrains of moral denouncements like those of Ibn Taymiyya, went the quiet but pervasive daily business of interest-bearing loans and office sale.

\section{Waqf as Strategy}

If we turn to the extant archives, most of which consist of endowment deeds and their subsequent paper trails, a pattern emerges that deserves a brief comment. As some scholars have noted, a majority, though by no means all, of the existing documentary collections belong to non-Muslim communal authorities. Here we may cite the archives of the Coptic Patriarchate Archive in Cairo, the Greek Orthodox Patriarchate Archive of Alexandria, St. Catherine's Monastery Archive in Sinai and even the small trove of documents of the Karaite community in Cairo. ${ }^{49}$

These archives consist of documents issued by Muslim courts, albeit in favour of individual dhimmīs. In most cases, these dhimmis, eventually donated their properties in the form of charitable endowments in favor of their religious communities, e.g. assigning the rental income from a multi-story urban house to benefit the poor Christians of a particular neighborhood or the monks of a specific monastery. ${ }^{50}$ In addition to the salvific reasons for establishing these

49 To these we may possibly add the Family archive of Middle-Egypt Coptic rural archon family, the Banū Bifam (11th c.). For a brief description of the contents of this private archive, see Gaubert, C. "Remarques préliminaires sur les archives d'époque Fatimide d'une famille copte", Polish Archeology in the Mediterranean, IX (1999), 87-89.

${ }^{50}$ Chamberlain argues that on occasion, documents dealt with "ephemeral problems" which is why "there was little need to preserve them over long periods", Chamberlain, Knowledge and Social Practice, 17. 
$w a q f \mathrm{~s}$, the original dhimm $\bar{\imath}$ owners of these properties increasingly turned to charitable endowments, again concluded at Muslim courts according to the prescripts of Islamic law, in order to protect their patrimony, for while they technically donated the income from their assets to charitable ends in perpetuity. Setting up an endowment allowed them to specify themselves (and their progeny thereafter) as administrators and supervisors of the endowments, services for which they derived handsome salaries.

If we restrict our attention to extant archives it appears that we have a distinctly dhimmi pattern. ${ }^{51}$ However, these collections despite being separately housed by dhimm $\bar{\imath}$ authorities, belong to the larger corpus of endowment deeds in later-medieval Egypt-Syria. Their contents evidence the increasing preference for founding endowments in Mamlūk society, a preference shared by dhimmī and Muslim communities alike.

If the type of document evidences a shared social and legal practice, then it is only the form of the archive -its centralization and longevity - that is different. Here, that form is likely a function of the stable institutional continuity of these dhimm $\bar{\imath}$ communal authorities. $^{52}$

Not only were these communal bodies distinct by their historical longevity, but it is important to note that despite these various dhimmi authorities' vocal protestations and threats of social and spiritual sanction, their congregations consistently availed themselves of legal services at Muslim courts, side-stepping their own communal courts, and more importantly, their legal traditions. There are various reasons for this preference, but perhaps most importantly was dhimmīs' anticipation of future challenge and conflict, be it legal or otherwise, by the state or by neighboring Muslims. This surely contributed to

${ }^{51}$ At least this is the framework according to which Chamberlain dismisses these cases as mere "exceptions" that prove his general rule regarding the absence of archive and distrust of documents.

${ }_{52}$ This is similar to the case of documents from early-medieval Europe, the overwhelming majority of which come from (and relate to) churches and monasteries. See Brown, W., "Conflict, Letters, and Personal Relationships in the Carolingian Formula Collections", Law and History Review, 25 (2007), p. 330. See also Chris Wickam's introductory remarks to his discussion of early-medieval documents preserved in European church archives in Wickam, C., "Land Disputes and Their Social Framework in Lombard-Carolingian Italy, 700-900", in W. Davies and P. Fouracre (eds.), The Settlement of disputes in early medieval Europe, Cambridge, 1986, p. 105. 
dhimmīs' assiduous compilation and preservation of documentary evidence that confirmed their rights and privileges. As the 9th-century al-Tahāwī explained, documents were intricately connected to conflict. $^{53}$

It is perhaps not an exaggeration to note that endowment deeds which constitute the single largest corpus of extant documents, represent the most important -and most socially ubiquitous and centraltype of legal instrument in Mamlūk society. For a variety of reasons -a series of developments we may call the wider property regime of Mamlūk society-individuals and groups increasingly turned to establishing charitable foundations not only as a way of protecting patrimony, but also as a way of ensuring its favorable transmission over generations. Interestingly, such preference was shared by both the military and scholarly establishments, by both Muslims and nonMuslims; indeed, insofar as it enjoyed widespread popularity, it was the hallmark of a wider legal culture.

Waqf also created various fiscal and administrative linkages between agricultural assets in the countryside and the urban institutions they financed. In its urban contexts, endowments spun intricate webs of service and dependence, loyalty and patronage -ties, which ultimately produced social groups and communities. Setting an endowment was first an act of translation -of converting one form of capital into another, from wealth to status and piety. But like the archive itself, it was also a charged act bound up as much in the past as it was in the future. The founder alienated property s/he had accumulated over past years but in so doing, they ear-marked and qualified its future disposition. As in other places like Ancien Régime France, this act

${ }^{53}$ A recent British newspaper article informed that roughly half the agricultural plots of England and Wales are not registered in the UK National Land Registry; moreover, it is usually the largest plots of land which are unregistered (arguably those with the least eventful histories of property transfer and/or challenge), in "Finding Out Who Really Owns Britain Isn't Easy", Sunday Times, 8 January, 2006. Sijpesteijn argues that in such cases, "the threat of a challenge to their possession is sufficiently remote that the owners feel taking the precaution of having their title formally recorded unnecessary" (Sijpesteijn, P., "The Archival Mind in Early Islamic Egypt: Two Arabic Papyri", in P. Sijpesteijn, L. Sundelin, S. Torallas and A. Zomeño (eds.), From al-Andalus to Khurasan. Documents from the Medieval Islamic World, Leiden, 2007, 163-186, 163, n. 2). A similar logic obtains in the case of our dhimmī property/archives: here nonMuslims' fear of future conflict and challenge underwrote their careful preservation of evidence that confirmed their privileges. 
was often done to protect patrimony from the possible depredations -not only by the state or potential enemies, but also future progeny. Thus, waqf as archive was a moment suspended between the preservation and protection of the past and the anticipation of future uncertainties.

Here it is instructive to recall J.-C. Garcin's thesis regarding waqf in medieval Middle East: "La transmission du patrimoine n'est peutêtre pas au centre de la problématique musulmane". ${ }^{54}$ Instead, under the endowment regime, the transmission of patrimony was secured by its alienation into a pious endowment and subsequently assigining revenues from that endowment to progeny, either as administrators of the endowment, or as incumbents of the salaried positions it included.

The term "musulmane" is, at first glance, inaccurate -especially given the preponderance of extant non-Muslim achives. But on a deeper and perhaps more meaningful level, Garcin's "musulmane" here, which may be better translated as 'Islamicate', refers to the wider legal culture at the center of which stood charitable endowments. Here the existence and histories of dhimmi collections are more than an exception to the (Islamic) rule: they remind us of the cumulative cultural effects of dhimmi reparation to Muslim courts and their use of Islamic law to conduct their daily and communal affairs. For as waqf became the crucial lifeblood of these communities -guaranteeing them enforceable, legally protected rights that were relatively better guarded from the encroachments of powerful umara' and the state Treasury- this very safeguard had an effect on the internal dynamics, if not the very constitution, of these communities. ${ }^{55}$

${ }^{54}$ Garcin, J-C., "Le waqf est-il la transmission d'un patrimoine?", J. Beaucamp and G. Dagron (eds.), La transmission du Patrimoine. Byzance et l'aire méditerranéenne, Paris, 1998, 101-109, 106.

55 An important qualification here relates to the kinds of endowments that dhimmīs were entitled to make: unlike their Muslim neighbors, non-Muslims in late-medieval Egypt could only set up charitable (khayrī) but not family (ahlī) endowments. This distinction is more significant in theory than it was in practice, especially given the practical uses to which waqf was put to protect familial interests -even in those cases of pious endowments. For ahlī and khayrī waqfs as forms on a continuum -rather than binary and qualitatively different forms- see Ghazaleh, P., "Introduction", in P. Ghazaleh (ed.), Held in Trust: Waqf in the Islamic World, Cairo, 2011. My warmest thanks to Pascale Ghazaleh for sharing her introduction before publication. 


\section{A Slipper-Like Folded Document and a Filed Geniza Petition}

If the above collections suggest a general pattern, it is important to note that not all extant collections were non-Muslim. Here I cite just one: Quseir al-Qadim archive of Abū Mufarrij, a Muslim family involved in Red-Sea trade (early-13th c.). ${ }^{56}$ The survival and integrity of this collection, which was preserved under a rubbish is arguably based on historical accident. But while these documents' survival until today may have been accidental this does not mean that such documentary collections had not existed earlier as archives. Indeed, Li Guo argues that the documents found at "the Sheikh's house" represented a multi-generational business archive of a Muslim merchant family (even other documents not related to the family business were deposited there because other individuals had used the notable's house as a postal address, i.e. like a PO Box). ${ }^{57}$

Furthermore, there are other clues in several documents that confirm the collection's earlier collection, purposeful protection, and preservation. Here it resembles the archive of the 11th-century rural elites of Fayyūm, Banū Bifam, who carefully preserved documents especially ones that detail commercial relationships and transactions or the documentary collection of their coreligionists, the Coptic family of Agathon and Rafael of Teshlot, in Middle Egypt. ${ }^{58}$

One rather pathetic item stands out: an unusual object consisting of a sheet of paper that was folded into an equilateral triangle. According to the archaeological report that describes the document, the folding was clearly "conducted with great care" and "closed the sheet irrevocably upon itself". Given that the object derived from a trash heap of Ayyubid remains (13th c.), probably formed during the Mamlūk period, some of the writing on the paper has been erased by mechanical action -and the corners of the original triangle worn out and eroded by organic matter. ${ }^{59}$

56 On this collection, see Guo, L., Commerce, Culture, and Community in a Red Sea port in the thirteenth century: The Arabic Documents from Quseir, Brill, 2004.

57 Guo, Commerce, Culture, and Community, 10-25.

${ }^{58}$ Gaubert, C. and Mouton, J-M., "Présentation des archives d'une famille copte du Fayoum à l'époque fatimide", in M. Immerzeel and J. van der Vliet (eds.), Coptic Studies on the Threshold of a New Millennium, Leuven, 2004, pp. 505-17. For the Teshlot archive, see Green, M., "A Private Archive of Coptic Letters and Documents from Teshlot", Oudheidkundige mededeelingen/Rijksmueum van Oudheden te Leiden, 64 (1983), 61-122.

${ }^{59}$ For a short summary of the physical description reproduced here, see Regourd, A., "Folding of a Paper Document from Quseir al-Qadim: A Method of Archiving?", Al- 
The object originally consisted of two papers: a smaller written fragment was lodged inside a larger paper (the larger piece a rectangle, the smaller a square). The folding along the diagonal produced an equilateral triangle, which was then re-folded into a "slipper-like" object that practically sealed the paper upon itself. The two pieces in this forensic puzzle ended up being parts of a single document, one of the longest commercial letters in the Quseir collection. Problems of erosion limit legibility now, but we can clearly identify opening formulae, main body, closing remarks, etc. Indeed, from the legible lines, it seems highly likely the letter is associated with the main company of Abū Mufarrij.

The most interesting part of this puzzle is the shape of the document -or rather how and why it ended up looking like this. Clearly the original document was intentionally cut up into the two pieces; this makes it highly unlikely that the tear (which, after all, occurred before the very deliberate folding) was accidental. Anne Regourd argues that tear and folding practice worked like the diagonal crossing-out of other documents. In both cases, the gestures clearly preserve the original content, including access to its written content which is not erased or crossed out to the point being illegible -while clearly indicating some expiration. We can only speculate about the significance of these deliberate acts: e.g. in commodity lists, do the strikes indicate goods delivered or paid for? Do the rights refer to those of buyer or seller?

But again, what is very interesting is the careful convention by which a once-valid document is cancelled out but still preserved. Here we are deliberately including merchants' letters in discussing of (the Quseir) archive while these were not court-issued documents, per se, the manner by which these were transacted among merchants makes them practically -in both senses of the word- official and binding. ${ }^{60}$

'Ușūr al-Wustā', 20 (2008), 13-16. Many thanks to Anne for sharing her article and generous account of the dig and other archeological reports related to the site. On this document, see Guo, Commerce, Culture, and Community, 254-55, verso line 4.

${ }^{60}$ This protocol for cancellation recalls earlier parallels, e.g. the 3rd-century documents of sale of slaves discovered in Mesopotamia, where several documents were intentionally damaged by putting diagonal bars on crossed-out papers in order to cancel (prior) obligation. Feissel, D., Gascou, J. and Teixidor, J., "Documents d'archives romains inédits du Moyen Euphrate", Journal des Savants, 6-7 (1997), 3-57. 
Not all cancellation was so explicit. Our next brief example comes from the Geniza -the other, large collection of documents from the pre-Ottoman Middle East. Scholars like S. Goitein and M. Cohen, have repeatedly emphasized the ideological (religious) basis of the Geniza collection and preservation- so much so that Goitein called the Geniza, with its inclusive logic or preserving any document in Hebrew and/or with God's name, the "opposite of an archive". ${ }^{61}$ But while this may be true for the depositing and general principle of genizot, the Ben Ezra synagogue clearly contained dozens of official Arabic documents issued by Muslim courts and chanceries. ${ }^{62}$ These were clearly purposefully kept by the Jewish community for some time -before either being re-used or discarded in the synagogue's Geniza. But here too, the absolute statement of the collection's religious/ideological basis has often precluded more careful scholarly attention to the medieval life of archival collections.

In a recent article, Marina Rustow edited an Arabic petition from the Oxford collection of Geniza manuscripts: ${ }^{63}$ based on her careful forensic work, the document turns out to be a petition addressed to a woman at the Fătimid court, regarding the endowment of an Ismāêli mosque: in other words, it had very little to do with the Jewish community. In a section in which she thoughtfully considers the document's path to the Geniza collection, Rustow convincingly argued that the petition was most likely preserved as a draft or model for addressing state officials. It is unlikely that this is the only such document and Rustow has discovered dozens of such official documents, which she traces to the crucial role played by Jewish courtiers as mediators for their community.

In this case, the document's subsequent recycling -its use for Hebrew letter exercises by an inexperienced hand- is datable to a later period; it was likely discarded when the stylistic protocols observed in addressing the 11th-c. Fātimid court had expired -either

${ }^{61}$ Because it stored documents that were deemed worthy of disposal rather than preservation (Goitein, S., A Mediterranean society. The Jewish communities of the Arab world as portrayed in the documents of the Cairo Geniza, Berkeley/Los Ángeles, 1999, 1:7).

${ }^{62}$ Khan, G., Arabic Legal and Administrative Documents in the Cambridge Genizah Collections, Cambridge, 1993.

${ }^{63}$ Rustow, M., "A Petition to a Woman at the Fatimid Court, 413-4 a.h./1022-3 c.e.)", BSOAS, 73 (2010), 1-27. My thanks to Marina for sharing her material before the article was published-and for lively and exciting discussions of the problem in general.

Al-Qantara XXXII 2, julio-diciembre 2011, pp. 389-434 ISSN 0211-3589 
with diplomatic innovations, or regime change. But the case demonstrates that behind the correct genealogy of the Geniza collection as a religious practice, lies the reality of numerous other documents, which were purposefully preserved, in this case as models or formularies for drafting similar petitions to the state.

These examples suggest that there were systematic protocols for canceling expired documents after they had been preserved and collected. As such, they remind us that such documents had a life-cycleindeed, that the 'destruction' or discarding were not accidental events, but part of the deliberate and purposeful manner by which documents were handled.

\section{Al-Maqrīzī's Draft Notebook: The After-Life of a Document}

In the early 15th century, when the famous Egyptian historian al-Maqrīzī took down some notes as research for his monumental Khitat, a topographical guide of Cairo, he used a piece of scrap paper, which was actually a recycled page. One side of it had been used but the blank side was subsequently deemed useful enough to re-use. The biography of this scrap of paper constitutes one rare window onto the social world of Medieval documents and archives. ${ }^{64}$

Through a careful forensic investigation -and, we must add, because the Mamlūk chancery observed such a rigid and differentiated style-book for drafting documents depending on the recipient's rankFrederic Bauden was able to exactly identify the document which had been first published by the Chancery Bureau on the page's recto ${ }^{65}$ It consisted of a decree granting an amīr a piece of agricultural land as $i q t \bar{a}$; ; the recipient was a Bedouin chief named Baligh and the $i q t \bar{a}$ ' represented a reward from helping sultan Ismā'îl consolidate his power and eliminate the rival contender to the throne, his brother Aḥmad (both were sons of al-Nāṣir Muhammad). This

${ }^{64}$ Al-Maqrizi's notebook also sheds light on the famous historian's compositional methods see Bauden, F., "Maqriziana IV. Le carnet de notes d'al-Maqrizi: l'apport de la codicologie à une meilleure comprehension de sa constitution", Manuscripta Orientalia. International Journal for Oriental manuscript Research, 9 (2003), 24.

${ }^{65}$ Bauden, F., "The Recovery of Mamluk Chancery Documents in an Unsuspected Place" in A. Levanoni and M. Winter (eds.), The Mamluks in Egyptian and Syrian Politics and Society, Leiden, 2004, pp. 59-76. 
took place in 744/1344, amidst the intense power struggles and insurrections, which brought no fewer than eight of al-Nāsir's sons to the throne in the twenty years immediately following his death.

Based on numerous clues, from the style, size, format, as well as the document's contents, Bauden also reconstructs the historical incident that led to the production of this document. In fact, such a manshür, or grant of iqtā', was drafted in duplicate: one copy was sent to the recipient, the other remained in the archive of the Chancery Bureau. Interestingly, it is the latter copy that survive today, a document which was produced by, and preserved in, a central state archive.

Now the document was drafted and issued in 744/1344. Other sources relate that in 790/1388, political instability culminated in a coup d'etat; during the chaos, the Chancery's archive was ransacked, its contents sold as scrap paper by weight. Al-Maqrīzì himself was personally familiar with the archive since he worked in that same bureau as a secretary until that date. This is how al-Maqrīzi not only came to know about and report the incident of the archival theft, but also gained access to these documents-in their new state: as scrap paper. ${ }^{66}$

The biography of this piece of recycled paper and the events that underwrote its production and preservation as an official document clearly indicate that state archives were systematically maintained, except during unusual periods of extreme political instability. The last detail affords us a rare glimpse of the end of this document's career (and the beginning of its afterlife as scrap paper). Again, the picture reveals that documents were highly valued; even a Bedouin commander -the epitome of nomadic mobility which stands in sharp contrast to the stability of state archives- negotiated his rights using an official document. ${ }^{67}$

${ }^{66}$ We know little else about Baligh, whom the sources return to historical oblivion after the mid-14th century.

${ }^{67}$ It is worth a brief pause to note that two of our examples related to Bedouins' relations with the state (first the St. Catherine's fatwa , second the writ to Amir Baligh). Of course other examples could be adduced for my argument, including many that do not pertain to Bedouins in any way, but perhaps the repeated appearance of bedouins is also suggestive here: in the context of the centralizing reforms of the Mamlūk state, the Bedouin increasingly assumed the symbolic role as the state's disruptive (anarchic) other. But it was through legal resources-from decrees/missives that threatened sanctions, to iqt $\bar{a}$ ' grants that promised rewards-that Bedouin chiefs like Baligh were integrated into the Mamlūk state's webs of loyalty and patronage (including a new office, amir al-'urban, which recognized their leadership and made them accountable to the state). 
Baligh's biography and story reveals not only how a document was archived, but also how both original and duplicate decrees had, in all likelihood, effectively expired before they slipped back into oblivion (with Baligh's death or dismissal, which most likely occurred before 790/1388). At the moment of "expiration", documents became pieces of paper, i.e. they ceased to hold that vital affective link of signification between a document and the property and resources it refers to. But the rest of Baligh's life most likely involved commissioning other documents, this time, waqf deeds, which likely survived for decades, if not centuries, after their publication. ${ }^{68}$

Here, and no doubt in many other cases, the theft of the chancery documents was driven by the high demand for paper, which on turn derived from the production of various texts, including documents. Such high demand then was ultimately related both to the relatively high levels of literacy and an increasingly sophisticated legal culture that produced a thick documentary trail. In other words, here the very loss of documents was ultimately related to the wider social investment in cultural production and legal archival practice.

\section{Archival Violence and The Logic of Dispersal}

The sacking of the Cairo Citadel archives demonstrates that the significance and value of documents could elicit not only careful preservation, but also purposeful symbolic violence. Here documents were robbed not only because they could fetch a price on the secondhand paper market, but also as a deliberate act of erasure -in this case, of the previous regime.

Indeed this pattern is observed in numerous instances of rebellion and regime change. Earlier in the same decade, albeit all the way in England, the Wat Tyler Rebellion, or Great Uprising of 1381, saw peasant rebels systematically target and burn down hundreds of state archives precisely because they constituted symbols of authority. Indeed attacking a regime's archives was one of the most expressive

${ }^{68}$ Interestingly, and according to the above-mentioned practice, Baligh's high rank meant his decree boasted the glaring white and waste of wide line spacing. This made it the prime target and most ideal candidate for recycling as scrap paper, i.e. condemnation to the historical waste-basket of oblivion. 
acts of political insubordination. ${ }^{69}$ Here, as in other purposeful acts of destruction, violence was not an anarchic or inarticulate explosion of resentment, but a purposeful act aimed at sovereignty by attacking its most important symbols. ${ }^{70}$

What these acts share is a logic of purposeful violence that recalls the ancient Roman practice of damnatio memoriae -the punitive condemning of the memory of a ruler or other individual to oblivion. Archival violence could often be as deliberate and as complete. For the most successful act of damnatio memoriae is the most frustrating for the historian: its success lies precisely in its invisibility- its complete effacement of any trace, not only of the object in question, but also the very act of erasure. ${ }^{71}$

For our purposes here, these historical cases and practices underscore the importance of the temporality or life-cycle of medieval archives. Just because some archives did not survive until today is not evidence of their insignificance. In some cases, it was precisely their symbolic charge as remnants of earlier authorities that made them lightening rods of symbolic violence -by rebels and new administrations alike. Here we must also remember that institutional and symbolic violence need not always be direct: it is memory that requires careful upkeep and active preservation; sometimes it is just as effective, albeit slower and less dramatic, to let traces slip into oblivion through policies of indifference and neglect.

Furthermore, given that political regimes were often identified with their documents and archives, several new dynasties in medieval Egypt-Syria, made concerted efforts to enunciate their new identity by revising the old regime's chancery conventions -thus systematically proclaiming the expiration of the old. Such policies of radical notarial revision did not directly involve destruction, but they condemned old documents to an almost magical transformation back into paper. Such

${ }^{69}$ I rely on the account of Justice, S., Writing and Rebellion: England in 1381, Berkeley, 1994.

${ }^{70}$ For several similar cases related to moments of regime change in Egypt see Ayman Fu'ād al-Sayyid's introduction to his new edition of al-Maqrīzī, Mawā'iz wal-itibār bi-dhikr al-khitat wa-l-athär, London, 2002-7; 1: 109-11 and his note to an incident of archival destruction in the late-12th century (al-Khitat, 3: 731-1).

71 Thus the decision to bring about "disappearance" may also be part of wider archival strategy including practices, whose success lies precisely in altering, erasing, or even destroying once-archived documents. 
policies of instant notarial obsolescence culminated in the recycling of documents such as the abovementioned draft Fatimid petition, which was relegated to a (poor) handwriting exercise sheet before being deposited in the Cairo Geniza.

Derrida dubbed the passage of documents into the spaces of the archive a "house arrest". ${ }^{72}$ Another momentous transformation occurred when a document ceased to possess any legal import, when it was practically transformed back into a piece of paper. This passage also features in the story of archives. In the case of Mamlūk Egypt, this took place for various reasons, including theft and symbolic/ political violence. But rather than read from this incident of paper theft a general mistrust of documents -indeed, the opposite was more likely. For the theft was driven by the expected resale price of scrap paper. Thus, in 1292, when a fire reached the state archives, millitary slaves looted their contents and sold them in the paper market. ${ }^{73}$ In the theft of the Chancery Bureau in the 1380s, scrap paper fetched a handsome price; in fact, between the early 14 th and early 15 th century, the price of paper had doubled..$^{74}$

\section{Absence and Erasure as Strategy}

The cases presented and discussed here force us to rethink the central and absolute value ascribed to 'presence'. In the abovementioned case of Bint Shamla's case of conversion, we must recall that for her own conversion to Islam, she undoubtedly received a conversion certificate. Indeed, contemporary formularies list templates for such a document, suggesting their regular production. ${ }^{75}$ But we have yet to uncover any of these documents. Here too, the absence or silence of the record likely represents more than a trick of source survival. Elsewhere I have argued that this putative absence represents the trace of longer-term imaginative practices, whereby converts

72 Derrida, J., Archive Fever: a Freudian Impression, Chicago, 1996, 4.

3 Al-Maqrizī, Khițtat, 3, 683.

${ }^{74}$ Ashtor, E., Histoire des prix et des salaries dans l'Orient medievale, Paris, 1969, 366; al-Qalqashandī, Subh, 11: 132.

75 This would have been especially common during the mass conversions of the 8th/14th century in Egypt, though mostly for Coptic converts to Islam, and not Jewish converts, like Bint Shamla were far fewer and converted in isolated and personal cases. 
and especially their progeny gradually push back the dates of their conversion and ultimately reimagined their historical origins. In due course, conversion certificates would have become inconvenient counter-testimony to the more critical project of integration into the Muslim community (and sealed by an ultimate ethnic conversion to an Arab identity) -an acculturation based on a collective amnesia or erasure of history (i.e. the historical moment, and context, of conversion).

In such instances, we have to confront and interpret the alternative projects and priorities of social actors and the effects these had on the historical record. In the case of cultural processes like integration into the new religious community, the disappearance of the legal trace (dated conversion certificates), was the precondition for the deeper project of re-imagining the past. Absence and silence could, in other words, be positively sought out; in such ruses of invisibility, the very success of a social strategy relies on altering, or even eliminating the traces it leaves in the official record.

As we have seen in Ibn Țawq's register, such ruses of invisibility were not restricted to long-term acculturation, but were often the hallmark of quotidian practices, from office devolution in endowed institutions to the daily grind of interest-bearing loans. In order to properly understand these social practices -especially given the ways they were habitually veiled by elliptical representation and legal subterfuge- we need to restore documents to their wider social setting, to investigate not just their content and form, but also the work they were asked to perform by their 'authors.' In this sense, medieval documents were anything but the transparent and consistent tools of an efficient and rational Weberian bureaucracy, but rather the selective traces of particular strategies.

Thus, the historical absence that is traditionally read as lamentable lacunae in the historical record, could work on at least three different levels. First the absence (or disappearance) of central archives could be part of political of symbolic violence, whereby destroying archives constituted a deliberate political act and message. On another level, and to the degree that documents were ultimately related to the wider property regime, the consolidation or dispersal of particular archives was related to the type of property owned and those strategies of persons and groups to consolidate, protect and transmit such patrimony. Such strategies, as we have seen in numerous cases recorded 
by Ibn Tawq, could hinge on absenting or occluding specific practices from the record. Last but not least, when the very existence of certain documents contradicted or obstructed more meaningful cultural processes -as in the case of conversion certificates vis-à-vis acculturation and integration- disappearance or erasure could itself be a part of 'positive' practices of self-fashioning and self-representation.

\section{By Way of Conclusion}

I argued that instead of searching for the archives (as a fixed and static entity, often defined with reference to a normative European history), it is more productive to reconceptualize this inquiry into the value of documents in medieval society and the uses to which they were put. Once we transform this investigation into one of "archiving practices", then we can discover several collections, including fatāwa that performed the same work for their owners and were therefore carefully preserved and collected in the same manner as traditional archives. I made this argument for the St. Catherine's monastery collection of fat $\bar{a} w \bar{a}$, which was clearly preserved (a) based on an appreciation of the valuable contents of these responsa; and (b) purposefully archived with an eye towards retrieval in the case of future conflicts.

By examining several detailed cases, which provided clues about the life-cycle (and after-life) of documents, we were able to restore the crucial dimension of temporality in medieval archives: these cases demonstrate that even the many archives that do not survive until today, were at some point -and for extended periods - carefully preserved, by communal authorities, families, or individuals. Indeed, some of these cases document the manner by which (official or state) archives were destroyed; here, I argued that such acts resembled the Roman practice of damnatio memoriae and evidenced not only the currency and significance of documents, but their symbolic charge as signifiers of political sovereignty.

The larger point of these different cases is to suggest an outline for a research agenda of medieval Arabic archives, a historical inquiry in which we step beyond the evidence of today's physically intact and extant archives to a deeper forensic examination of the lives of docu- 
ments and archives, biographies which include not only moments of production and preservation, but also destruction and passing away. Such a project require archivists to delve into narrative and biographical sources. It is also necessarily interdisciplinary: it simply will not do to treat documents only through erudite and neatly published editions. We need to wade through numerous archaeological reports to discover not only the contents of a document, but also learn something about its relative position and final form, before some intrepid historian unfolded it to read the inside. In other words, such a project will restore to documents their tactile physicality, which often contains various clues about the biography and social value of the document-as object, especially in medieval society where various types of documents and texts were valued and revered, cherished and brandished, not only for their textual content, but also their physical attributes and authorizing stamp of their authors/creators ${ }^{76}$.

This is a far cry from Chamberlain's image of an elite scholarly averse to documentary evidence, a space where competition and conflict are waged only through ritualized performances of piety and erudition -in short, a highly symbolic and enchanted world that stands in contrast to rational and standardized Weberian bureaucracy. Paper and text only emerge -as formalized literary accounts of these events: for Chamberlain, this is the domain of prosopography, where scholars only competed over ideal representations of the past. This is a world where figures like Ibn Țawq and Bint Shamla, the provincial merchant family of Abū Mufarrij and the monastic communities of the Georgians and Greek Orthodox, are all silenced by relegation to the sidelines of Chamberlain various "exceptions".

By contrast, the work of subsequent critics of Chamberlain, suggests a world of consistent and rationalized bureaucracy. Sijpesteijn, for example, analyzes bureaucratic documents to argue for "a recordkeeping habit" and "by extension, the Muslim bureaucratic instinct", what she rather mystically dubs "the archiving mind", for her, are

${ }^{76}$ Indeed in discussing the $q \bar{a} d \bar{l}$-court's central archive, Hallaq demonstrates that the dīwān of copies was constantly being copied -literally, coming into being and passing away- as it devolved from one judge to his successor. Once the new version came into existence, the older version immediately became obsolete and lost all its oficial, legal carácter instantly becoming a mere thing (a transformation powerfully dramatized by the image of these documents' sale "by weight"), see Hallaq, W.B., "The qā (sijill) before the Ottomans", BSOAS, 61 (1998), 415-436. 
evidence of "the bureaucratic and administrative sophistication that the Muslims brought to their empire". ${ }^{77}$ Although Sijpesteijn's work has revealed invaluable details about focused on state fiscal and administrative practices in early-Islamic Egypt, conceptualizing these rich findings as a matter of the "mind" obscures the crucial question of agency and location by vaguely extending them into a cultural attribute and a culturalist explanation (even if the final verdict is the presence of said mind). Moreover, the elastic term assumes that such an entity can be neatly transposed across space and time -thus leveling historical difference and closing us off to the possibility of questioning the very category of the archive, based on our historical data.

What is constant across both of these diametrically opposed readings of medieval archives is their shared and uncritical acceptance of the archive as a stable historical category. This forecloses any specific investigation of the unique logic or practices, i.e. precisely what makes medieval Arabic archives medieval.

By contrast, the cases we have examined demonstrate that documents and archives in medieval society could be but selectively preserved traces of wider practices that were purposefully excluded from the record. For the record was ultimately a resource that social actors availed themselves of -and in certain cases, complete visibility was neither sought nor desired. Indeed, in some cases, invisibility was the hallmark of success. The world of Ibn Țawq and the careful crafting of fatwa questions by Christian monks was anything like either vision of archival culture. Unlike Chamberlain's bold assertion, late-medieval Damascus was awash in documentary production; and pace the impression of an "archival mind" it is precisely those cases denoted by elliptical phrases and marked by an "incomplete" legal trace that are potentially most productive for a local, contextual understanding of the medieval archive and the notarial culture in which it was embedded.

The historical anthropology of the archive must resist the traditional severing of the event from its traces. It must go beyond analysis of the trace alone and step back to a wider view that includes those practices and worlds that produced these traces. In other words, it must move from a static focus on impressions and traces to a more productive view of those very acts and contexts that produced them.

77 Sijpesteijn, "The Archival Mind", 165 and 166.

Al-Qanțara XXXII 2, julio-diciembre 2011, pp. 389-434 ISSN 0211-3589 
We need to investigate an archival tradition with its distinctive conventions, conditions of production, and integral practical logic; to study a series of continuous and ongoing archival practices and strategies rather than searching for, and lamenting the absence of, a final form or object. Only then can we appreciate how the biography of an archive may contain not only moments of coming into being ("house arrest"), but also other moments of "disappearance", when archived documents were recycled back into paper. For this, we should remember that absences call for investigation and understanding too; indeed, sometimes they are just as much part of the story as presence. Thus we must learn to see the gaps in the historical record not simply as tears in the evidentiary fabric, but rather, in some cases, as part of the elaborate design woven by specific traces of particular practices. Only then can we arrive at a more dynamic social history of documents (and archiving practices) as tools of particular social strategies -and thus, to detailed analysis of how people deployed legal and archiving practices, but were also simultaneously fashioned by these strategies.

Recibido: 09/06/2011

Aceptado: 06/09/2011 